INTERNATIONAL JOURNAL OF RESEARCHES IN BIOSCIENCES, AGRICULTURE AND TECHNOLOGY (C) VISHWASHANTI MULTIPURPOSE SOCIETY (Global Peace Multipurpose Society) R. No. MH-659/13(N) www.ijrbat.in

\title{
PHYTOCHEMICAL SCREENING OF SELECTED MEDICINAL PLANTS USED FOR ANTI-UROLITHIATIC ACTIVITY
}

\author{
Supriya Waghmare and Dayanand Gogle \\ ${ }^{1}$ Chintamani College of Science, Pombhurna Dist. Chandrapur, Gondwana University, Gadchiroli, \\ Maharashtra, India. \\ 2PGTD of Botany, RTM Nagpur University, Nagpur. Maharashtra, India. \\ Corresponding author: email. Id :- dr.dayanand.gogle@gmail.com
}

\begin{abstract}
:
Medicinal plants have naturally occurring phytochemicals which are used for curing various human diseases. Plants are used as herbal drugs traditionally by tribal people worldwide. Medicinal plants have antifungal, antiinflammation, antianalgesic, diuretic, antiurolithiatic activities. The present study involves 11 different plant species viz. Tridax procumbens, Tribulus terrestris, Cassia fistula, Asparagus racemosus, Capsicum annum, Phyllanthus emblica, Citrus medica, Glycine max, Solanum lycopersicum, Psidium guajava, Citrus aurantium having antiurolithiatic activity. The main objective of the research work to check the presence or absence of the phytochemicals in all selected medicinal plants which are effective for antiurolithiatic activity.
\end{abstract}

Keywords: Medicinal plants, Phytochemical screening, Antiurolithiatic activity.

\section{INTRODUCTION:}

The world health organization (WHO) estimated that 4 billion people $(80 \%)$ of the world population presently use herbal medicine for one form of primary health care or another. Plants contain many active compounds such as alkaloids, Steroids, Tannin, Terpenoids, Flavonoids, Phenols, Cardiac glycosides which are present in different parts of plants roots, Leaves, stem, flower, fruits, seeds etc. and used to cure kidney stone disease(Aggarwal et al,2010. Agarwal et al. 2014, Lunavath et al.2014, Cambie et al, 1961). Urolithiasis derived from the Greek words "ouron" (Urine) and "lithos" (Stone). It is considered as the third most affliction of the urinary tract. It is one of oldest, most frequent and highly recurrent disease and was initially found in the tombs of Egyptian mummies dating back to 4000 BC. Urolithis are generally composed of Calcium oxalate monohydrate and Calcium hydrogen phosphate hydrate (75-90\%), Magnesium phosphate hexahydrate (10-15\%), Uric acid and urates $(3-10 \%)$ and $(0.5-1 \%)$ is composed of cystine. The surgical methods available to treat kidney stones like extracorporeal shock wave lithotripsy have serious side effects therefore it is worthwhile to look for an alternative for the managment of urolithiasis. Many medicinal plants have been employed during ages to treat urinary stones.

\section{METHOD AND MATERIAL:}

The all plant species were collected from different localities of Nagpur district and authenticated from department of Botany Rashtrasant Tukadoji Maharaj Nagpur University, Nagpur. They were cleaned, dried in shade and grinded to a coarse powder using grinder and then stored in airtight closed bottles until required. The shade dried (10g) powder of each plant material were filled separately in the thimble and extracted with methanol using a soxhelt extractor followed by evaporation.

Phytochemical screening:

For the phytochemical screening 8 bioactive compounds viz. alkaloids, saponins, terpenoids, tannins, phenolic compounds, terpenoids, flavonoids and cardiac glycosides were selected and Chemical tests of 11 plant species were carried out by using methanolic extract and standard procedures described by Sofowara (1993), Trease and Evans (1989) and Harborne (1973).

\section{RESULT AND DISCUSSION:}

The curative properties of medicianal plants are perhaps due to the presence of various secondary metabolites. These secondary metabolites have 
properties to cure various diseases. Thus the preliminary screening tests may be useful in the detection of the bioactive compound which are useful in dissolving kidney stone. The successive methanolic extracts of all 11 plant species have revealed the presence of Alkaloids, Saponin, Terpenoids, Tannin, Phenol, Steroids, Flavonoids, Cardicac glycosides in different parts of plants such as Root, stem, leaves, fruits, seeds etc. and results obtained were given in table no. 1. Maximum plant species shows presence of all selected bioactive compounds in less are more concentration. Glycine max seeds do not shows the presence of terpenoids, tannins, steroids, flavonoids, cardiac glycosides. This indicate that out of 11 plant sp. Glycine max was less effective for to cure kidney stone disease.

\section{CONCLUSION:}

Present study investigate presence of all selected secondary metabolites in more or less concentration in all 11 selected plant species which have antiurolithiatic properties. This research work has revealed further potential of this plant in the area of pharmacology as potential source of useful drugs.

\section{REFERANCE :}

Aggarwal A, Jandon S, Singla SK, Tandon C, 2010. Diminution of oxalate induced renal tubular epithelial cell injury and inhibition of calcium oxalate crystallization in vitro by aqueous extract of Tribulus terrestris. Int Braz J Urol Jul-Aug; 36(4):480-488.

Cambie, R.C., cain, B.F.and La Roche, S. 1961. A New Zealand Phytochemical Survey (III) Ferns and Fernallies, New Zealand J. Sci., Vol.4PP:707-714.

Dr. Venkanna Lunavath, Dr. Estari Mamidala, 2014. Antimicrobial activity and phytochemical study of Phyllanthus emblica fruit extracts, World Journal of pharmacy and pharmaceutical sciences Volume 3, Issue 8, 1489-1495.
Horborn J.B.1998. Phytochemical method,A guide to modern technique of plant analysis Chapmann and Hall London.

AgarwalKumkum; VarmaRanjana, 2014.Ocimum gratissimum L.:A Medicinal plant with promising Antiurolithiatic activity, International Journal of Pharmaceutical science and drug research; 6(1):78-81.

Muhammad Jawad Nasim 2014.; list of medicinal plants of Pakistan having ethnobotanical evidences to crush renal calculi (kidney stones), Acta poloniac Pharmceutica-Drug research Vol.71 pp.-3-10.

Prasad k, Sujatha D, Bharathi K, 2007. Herbal drugs in urolithiasis - a review. Pharmacognosy Reviews; 1(1): 175-179.

Trease G.E. and Evans, W.C. 1978, Pharmacology, $11^{\text {th }}$ Ed Bailliere Tindall Ltd, London; 60-75.

World health organization (WHO) Legal status of traditional medicine and complementary / alternative medicine: a worldwide review. Available from http:// libodoc. Who.int/hq/2001/WHO_EDM_TRM_2001.2 pdf. 
Table no.1. Phytochemical screening for selected medicinal plants used for antiurolithiatic activity

\begin{tabular}{|c|c|c|c|c|c|c|c|c|c|c|c|}
\hline Plant Name & 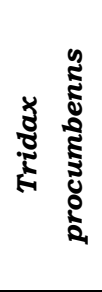 & 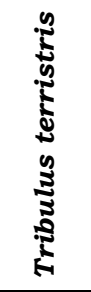 & 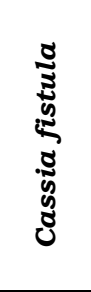 & 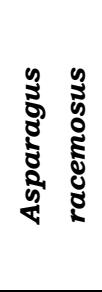 & 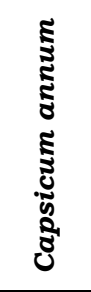 & 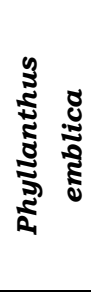 & 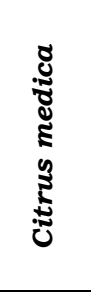 & 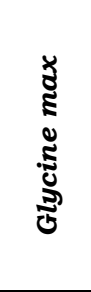 & 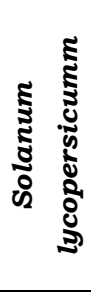 & 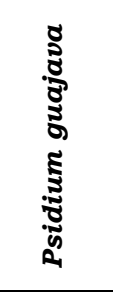 & 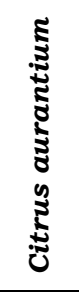 \\
\hline $\begin{array}{c}\text { Part of plant } \\
\text { used }\end{array}$ & $\begin{array}{c}\text { Whole } \\
\text { part }\end{array}$ & Fruit & $\begin{array}{l}\text { Fruit } \\
\text { pulp }\end{array}$ & Roots & Fruit & Fruit & Fruit & seeds & Fruit & Leaves & Fruit \\
\hline \multicolumn{12}{|l|}{ Alkaloids } \\
\hline Mayer's test & +++ & ++ & -- & - & -- & -- & ++ & ++ & ++ & ++ & ++ \\
\hline $\begin{array}{c}\text { Dragendorff's } \\
\text { test }\end{array}$ & +++ & ++ & +++ & +++ & ++ & +++ & -- & -- & ++ & -- & -- \\
\hline Wagner's test & +++ & +++ & +++ & +++ & +++ & +++ & ++ & ++ & ++ & ++ & +++ \\
\hline Saponins & - & - & - & - & - & - & ++ & ++ & + & ++ & ++ \\
\hline Terpenoids & +++ & - & +++ & +++ & ++ & +++ & +++ & - & +++ & ++ & +++ \\
\hline Tannin & +++ & ++ & ++ & - & ++ & +++ & ++ & - & ++ & +++ & +++ \\
\hline \multicolumn{12}{|l|}{$\begin{array}{l}\text { Phenolic } \\
\text { compound }\end{array}$} \\
\hline $\begin{array}{c}\text { Ferric chloride } \\
\text { test }\end{array}$ & ++ & ++ & + & - & +++ & +++ & +++ & ++ & ++ & +++ & + \\
\hline $\begin{array}{c}\text { Lead Acetate } \\
\text { test }\end{array}$ & ++ & +++ & ++ & +++ & +++ & +++ & +++ & +++ & ++ & +++ & + \\
\hline \multicolumn{12}{|l|}{ Steroids } \\
\hline Salkowski test & ++ & - & +++ & +++ & ++ & ++ & +++ & - & +++ & ++ & +++ \\
\hline Flavonoids & +++ & +++ & +++ & - & +++ & +++ & +++ & - & +++ & +++ & +++ \\
\hline \multicolumn{12}{|l|}{$\begin{array}{c}\text { Cardiac } \\
\text { Glycosides }\end{array}$} \\
\hline $\begin{array}{c}\text { Keller-killani } \\
\text { test }\end{array}$ & +++ & ++ & +++ & +++ & +++ & +++ & +++ & - & +++ & +++ & +++ \\
\hline
\end{tabular}

+ presence, - Absence 
